mgr inż. Joanna Czarnecka

Politechnika Poznańska

dr hab. Agnieszka Merkisz-Guranowska, prof. PP

Instytut Pojazdów Szynowych „,TABOR”

\title{
Ocena infrastruktury transportu intermodalnego w Polsce
}

\begin{abstract}
Transport intermodalny pociaga za sobq wiele korzyści zarówno w skali makro jak i mikro. W tym celu należy dażyć do realizacji szeregu kompleksowych działań, zapewniajacych transportowi intermodalnemu warunki rozwoju, w szczególności dostęp do odpowiedniej infrastruktury. Na efektywność tego typu transportu wptywa między innymi sieć terminali intermodalnych. Stabo rozwinięta infrastruktura uniemożliwia rozwój transportu kombinowanego. W Polsce parametry techniczne, w tym możliwości przeładunkowe i składowe, większości terminali sq niewystarczajace do obstużenia ilości ładunków wynikajacych ze strategii rozwoju transportu. Jednak prowadzone inwestycje w modernizacje istniejacych terminali oraz tworzenie nowych $w$ znacznym stopniu przyczyniaja się do polepszenia sytuacji Polski na europejskim rynku przewozów intermodalnych.
\end{abstract}

\section{Wprowadzenie}

Artykuł poświęcony jest zagadnieniu rozwoju infrastruktury transportu intermodalnego, ze szczególnym uwzględnieniem transportu kombinowanego drogowo-kolejowego. Kluczowym czynnikiem decydującym o efektywności transportu intermodalnego, a zwłaszcza o możliwościach przewozowych tej gałęzi transportu są terminale.

Intermodalny terminal przeładunkowy to obiekt przestrzenny $\mathrm{z}$ właściwą mu organizacja $\mathrm{i}$ infrastruktura umożliwiająca przeładunek intermodalnych jednostek transportowych: kontenerów, nadwozi wymiennych i naczep samochodowych pomiędzy środkami transportu należącymi do różnych gałęzi transportu oraz wykonywanie operacji na tych jednostkach w związku z ich składowaniem i użytkowaniem.

Polska dysponuje stosunkowo dużą liczbą terminali intermodalnych - kontenerowych. Średnia gęstość w przeliczeniu na powierzchnię kraju wynosi około 0,8 terminala na dziesięć tysięcy $\mathrm{km}^{2}$ i nie odbiega znacząco od średniej europejskiej $\left(0,9 / 10\right.$ tys. $\left.\mathrm{km}^{2}\right)$ [2]. Jest natomiast zdecydowanie niższa, niż w krajach o największym udziale przewozów intermodalnych w rynku kolejowym, takich jak: Holandia - 11,9, Belgia $-7,1$ i Niemcy $-4,1$. Stopniowy wzrost wolumenu i udział przewozów intermodalnych w Polsce, powinien przełożyć się w najbliższych latach zarówno na zwiększenie liczby nowych inwestycji terminalowych, jak również przyczynić się do unowocześnienia, w tym rozbudowy i modernizacji już istniejącej infrastruktury punktowej.

\section{Diagnoza istniejącej infrastruktury}

W Polsce funkcjonuje około 30 terminali intermodalnych, jednak mają one bardzo zróżnicowane parametry techniczne. Zestawienie podstawowych parametrów istniejących terminali transportu kombinowanego przedstawiono $\mathrm{w}$ tabeli 1 . W zestawieniu nie uwzględniono czterech wymienianych $\mathrm{w}$ innych źródłach terminali tj. dwóch terminali zamkniętych zlokalizowanych na terenie zakładów produkcyjnych $z$ uwagi na to, że nie są one dostępne dla osób trzecich (terminala $\mathrm{w}$ Zamościu, mieszczącego się na terenie Centrum Logistycznego Laude.pl i terminala w Świeciu firmy Mondi), terminala w Piotrkowie Trybunalskim należącego do operatora logistycznego CTL Logistics, który nie jest wykorzystywany oraz terminala Medyka Żurawica należącego do PKP Cargo, gdyż zgodnie $\mathrm{z}$ oświadczeniem operatora nie uczestniczy on w przewozach intermodalnych.

1/3 przewozów intermodalnych obsługują terminale zlokalizowane w środkowej części kraju (Warszawa, Pruszków, Mława, Małaszewicze, Kutno, Łódź, okolice Poznania), 1/3 obsługują pozosłałe terminale zlokalizowane na południu głównie na Górnym Śląsku (Sławków, Gliwice, Sosnowiec, Dąbrowa Górnicza) i Dolnym Śląsku (Wrocław, Brzeg Dolny, Kąty Wrocławskie). Terminale ze stref portowych Gdyni, Gdańska i Szczecina obsługują łącznie 1/3 polskich przewozów intermodalnych.

Dynamiczny wzrost przewozów morskich z krajów Dalekiego Wschodu, stwarza możliwości wzrostu przewozów kontenerowych, jednak możliwości te 
wykorzystywane są obecnie głównie przez transport drogowy. Transport intermodalny mógłby jednak przejąć ładunki w kierunkach wschodnich i południowych Europy, chociaż liczba terminali na wschodniej granicy Polski jest niewystarczająca. Obecnie największy z nich znajduje się w Małaszewiczach, który obsługuje około $6,4 \%$ kolejowych przewozów intermodalnych.

Polski transport kolejowy, przy realizacji przewozów intermodalnych, w 2011 roku obsługiwał miesięcznie średnio 66 tysięcy TEU ${ }^{1}$ o daje rocznie 792 tysiące TEU. Największe roczne możliwości przeładunkowe pojedynczego terminala lądowego wynosity 187000 TEU. Takie możliwości ma Centrum Logistyczne Małaszewicze. Drugi co do możliwości przeładunkowych jest Euroterminal Sławków obsługujący 105000 TEU. Jeden $\mathrm{z}$ najlepiej wyposażonych terminali $\mathrm{w}$ Polsce, terminal w Kutnie, obsługuje 100000 TEU rocznie. Wkrótce jego zdolność przeładunkowa wyniesie 200000 TEU.

W najbliższym czasie ma powstać kilka nowych obiektów w miejscowościach: Łosośna, Zajączkowo Tczewskie, Dorohusk, Konin, Poznań Franowo, Rzepin, Suwałki, Wrocław Brochów i Ostaszewo Torunskie, Brwinów oraz Kórnik.

\section{Analiza potencjału rozwojowego rynku prze- wozów intermodalnych}

W Białej Księdze dotyczącej założeń europejskiej polityki transportowej nakreślono strategię osiagnięcia konkurencyjnego i zasobooszczędnego systemu transportowego [3]. Wśród celów jakie zostały w niej wytypowane na rzecz utworzenia konkurencyjnego systemu transportu znalazły się wytyczne optymalizujące działania multimodalnych łańcuchów logistycznych. W szczególności przyjęto następujące założenia:

- Stworzenie do 2030 roku w pełni funkcjonalnej ogólnounijnej multimodalnej sieci bazowej TEN-T, a do 2050 roku osiagnięcie wysokiej jakości i przepustowości tej sieci.

- Zapewnienie opłacalności multimodalnego transportu towarów dla przewoźników poprzez wdrożenie specjalnie zaprojektowanych korytarzy transportowych, optymalnych pod względem wykorzystania energii i emisji oraz minimalizacji wpływu na środowisko, a także atrakcyjnych ze względu na niezawodność, ograniczone zagęszczenie ruchu i niskie koszty operacyjne.

- Zapewnienie zmiany strukturalnej niezbędnej do umożliwienia skutecznego konkurowania
- przez transport kolejowy oraz przejęcia większej proporcji transportu towarów na średnie i dalekie odległości poprzez znaczne inwestycje pozwalające na rozszerzenie lub unowocześnienie przepustowości sieci kolejowej.

- Przeniesienie do 2030 roku 30\% drogowego transportu towarów na odległościach większych niż $300 \mathrm{~km}$ na inne środki transportu, np. kolej lub transport wodny, zaś do 2050 roku powinno to być ponad $50 \%$.

Oceny stanu rozwoju transportu intermodalnego można dokonać zatem pod względem możliwości spełnienia zawartych w Białej Księdze założeń, w szczególności transferu 30\% ładunków z przewozów drogowych na przewozy kolejowe.

W roku $2011 \mathrm{w}$ Polsce przetransportowano łącznie 1912178 tys. ton ładunków, z czego transportem drogowym przewieziono 1596209 tys. ton, a koleja 248606 tys. ton [4]. Niestety nie są dostępne dane dotyczace struktury odległościowej przewozów transportem drogowym. Z tego powodu w celu obliczenia ilości ładunków, które powinien przejąć transport kolejowy, przyjęto dwa założenia. Pierwsze założenie stanowi, że obecnie $70 \%$ ładunków drogowych jest przewożonych na dłuższych dystansach, przekraczających $300 \mathrm{~km}$, drugie, że jest to połowa ładunków.

Dążąc do realizacji założeń Białej Księgi zgodnie z pierwszym założeniem należałoby dokonać transferu $30 \%$ ładunków, czyli 335203,9 tys. ton z transportu samochodowego na transport kombinowany. Przy założeniu, że jeden kontener 20-stopowy (1 TEU) mieści 0,0102 tys. ton wspomniane wyżej $30 \%$ ładunków stanowiłoby 32863126 TEU. Chcąc proporcjonalnie rozdzielić ten ladunek na istniejące 30 terminali każdy z nich musiałby obsłużyć 1095437 TEU.

Według drugiego założenia $50 \%$ ładunków przewożonych transportem samochodowym to ładunki na trasie powyżej $300 \mathrm{~km}$, czyli 798 104,5 tys. ton. $30 \% \mathrm{z}$ tej wartości stanowi ładunek o masie 239431,4 tys. ton, co odpowiada 23473662 TEU. Rozdzielając ten ładunek na 30 terminali każdy z nich musiałby obsłużyć rocznie 782455 TEU.

Zestawienie najważniejszych informacji związanych ze zwiększeniem udziału transportu kombinowanego w przewozach na odległość powyżej $300 \mathrm{~km}$ dla danych z 2011 roku zamieszczono w tabeli 2.

\footnotetext{
${ }^{1}$ Twenty-foot Equivalent Unit - miara odpowiadająca pojemności jednego kontenera 20 stopowego o długości $6,1 \mathrm{~m}$, szerokości 2,4 m oraz wysokości 2,6 m.
} 
Parametry techniczne terminali transportu kombinowanego drogowo-kolejowego

Tabela 1

\begin{tabular}{|c|c|c|c|c|c|c|c|}
\hline Terminal & 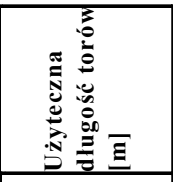 & 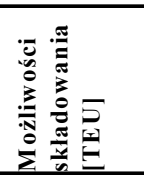 & 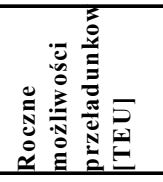 & 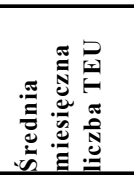 & 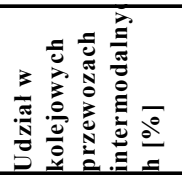 & 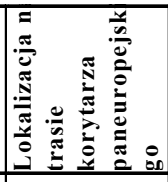 & 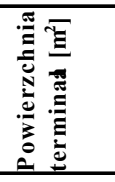 \\
\hline $\begin{array}{l}\text { TK Łódź Olechów } \\
\text { ul. Tomaszowska } 60\end{array}$ & $2 \times 700$ & 5000 & 60000 & 705 & 1,69 & II & 84000 \\
\hline $\begin{array}{l}\text { TK Warszawa Towarowa } \\
\text { ul. Ordona } 2 \mathrm{a}\end{array}$ & $2 \times 357,5$ & 1000 & 40000 & b.d. & b.d. & II & 18600 \\
\hline $\begin{array}{l}\text { TK Poznań Garbary } \\
\text { ul. Północna } 1\end{array}$ & $3 \times 150$ & 600 & 40000 & b.d. & b.d. & II & 6200 \\
\hline $\begin{array}{l}\text { TK Sosnowiec Południowy } \\
\text { ul. Kościelna } 60\end{array}$ & $3 \times 230$ & 800 & 30000 & 238 & 0,57 & III & 9500 \\
\hline $\begin{array}{l}\text { TK Kraków Krzesławice } \\
\text { ul. Łowińskiego } 2\end{array}$ & $2 \times 300$ & 600 & 40000 & b.d. & b.d. & III & 13300 \\
\hline $\begin{array}{l}\text { TK Dąbrowa Górnicza } \\
\text { ul. Koksownicza } 6\end{array}$ & $\begin{array}{l}3 \times 625 \\
1 \times 100 \\
2 \times 300\end{array}$ & b.d. & b.d. & b.d. & b.d. & III & $225000^{*}$ \\
\hline $\begin{array}{l}\text { TK Pruszków } \\
\text { ul. Przytorowa } 1\end{array}$ & $\begin{array}{l}2 \times 600 \\
1 \times 100 \\
2 \times 300\end{array}$ & b.d. & 90000 & 1448 & 3,47 & II & 32976 \\
\hline $\begin{array}{l}\text { TK Wrocław } \\
\text { ul. Krakowska } 1\end{array}$ & $\begin{array}{r}2 \times 3001 \times 250 \\
1 \times 190\end{array}$ & b.d. & 117000 & 1211 & 2,90 & III & 45000 \\
\hline $\begin{array}{l}\text { TK Gądki } \\
\text { ul. Magazynowa } 8\end{array}$ & $4 \times 6101 \times 610$ & b.d. & 28000 & b.d. & b.d. & II & $320000^{*}$ \\
\hline $\begin{array}{l}\text { TK Mława } \\
\text { ul. Dworcowa } 9\end{array}$ & $2 \times 300$ & 2000 & 53000 & 504 & 1,21 & - & 25000 \\
\hline $\begin{array}{l}\text { TK Kobylnica } \\
\text { ul. Dworcowa } 3\end{array}$ & $3 \times 300$ & 500 & 29200 & 785 & 1,88 & II & 9300 \\
\hline $\begin{array}{l}\text { TK Gądki } \\
\text { ul. Dworcowa } 32\end{array}$ & $1 \times 748$ & 1000 & b.d. & 2320 & 5,55 & II & 10350 \\
\hline $\begin{array}{l}\text { TK Warszawa } \\
\text { ul. Marywilska } 39\end{array}$ & $1 \times 320$ & 1200 & 85000 & 1373 & 3,29 & II & 24000 \\
\hline $\begin{array}{l}\text { TK Gliwice } \\
\text { ul. Reymonta } 32\end{array}$ & $2 \times 450$ & 800 & 80000 & 1008 & 2,41 & III & 65000 \\
\hline $\begin{array}{l}\text { TK CL Małaszewicze } \\
\text { ul. Kolejarzy } 22 \mathrm{~b}\end{array}$ & $\begin{array}{r}2 \times 1300 \\
1 \times 560\end{array}$ & 1310 & 187000 & 2115 & 6,36 & II & 19100 \\
\hline $\begin{array}{l}\text { TK Sławków LHS } \\
\text { ul. Dębowa Góra }\end{array}$ & b.d. & b.d. & 16000 & 930 & 2,23 & III & b.d. \\
\hline $\begin{array}{l}\text { TK Kutno Krzewie } \\
\text { ul. Intermodalna } 5\end{array}$ & $\begin{array}{r}4 \times 600 \\
(4 \times 700 * *) \\
\end{array}$ & 4000 & 200000 & 3479 & 8,33 & II & 80000 \\
\hline $\begin{array}{l}\text { TK Gliwice } \\
\text { ul. Portowa } 28\end{array}$ & $\begin{array}{r}2 \times 600 \\
(4 \times 600 * *)\end{array}$ & 1650 & 100000 & 3158 & 4,56 & III & 30000 \\
\hline $\begin{array}{l}\text { TK Brzeg Dolny } \\
\text { ul. Sienkiewicza } 4\end{array}$ & $\begin{array}{r}2 \times 300 \\
(4 \times 650 * *)\end{array}$ & 1000 & 7500 & 1506 & 3,60 & III & 14000 \\
\hline $\begin{array}{l}\text { TK Kąty Wrocławskie } \\
\text { ul. Fabryczna } 1\end{array}$ & $1 \times 640$ & 900 & b.d. & 644 & 1,54 & - & b.d. \\
\hline TK Włocławek Brzezie & b.d. & b.d. & b.d. & 522 & 1,25 & - & b.d. \\
\hline $\begin{array}{l}\text { Euroterminal Sławków } \\
\text { ul. Groniec } 1\end{array}$ & b.d. & 2000 & 105000 & 2115 & 5,06 & III & b.d. \\
\hline $\begin{array}{l}\text { TK Poznań } \\
\text { ul. Nowosolska } 40\end{array}$ & $3 \times 600$ & 1200 & 50000 & b.d. & b.d. & II & b.d. \\
\hline $\begin{array}{l}\text { TK Radomsko } \\
\text { ul. Kraszewskiego } 36\end{array}$ & $3 \times 600$ & 2500 & b.d. & b.d. & b.d. & - & b.d. \\
\hline $\begin{array}{l}\text { CLIP Logistics Swarzędz } \\
\text { ul. Rabowicka } 6\end{array}$ & b.d. & 800 & b.d. & b.d. & b.d. & II & 6500 \\
\hline Gdański Terminal Kontenerowy & 2 tory $=320$ & 11500 & 100000 & b.d. & b.d. & $\mathrm{Ia}, \mathrm{VI}$ & 67417 \\
\hline $\begin{array}{l}\text { Bałtycki Terminal Kontenerowy } \\
\text { Gdynia }\end{array}$ & $3 \times 300$ & 18000 & 750000 & b.d. & b.d. & VI & b.d. \\
\hline Gdynia Container Terminal & $4 \times 475$ & b.d. & 400000 & b.d. & b.d. & VI & 19100 \\
\hline $\begin{array}{l}\text { Deepwater Container Terminal } \\
\text { Gdańsk }\end{array}$ & $2 \times 620$ & 23000 & 1000000 & b.d. & b.d. & Ia, VI & 44000 \\
\hline $\begin{array}{l}\text { Terminal Kontenerowy DB Port } \\
\text { Szczecin }\end{array}$ & b.d & 3260 & 120000 & b.d. & b.d. & - & 35000 \\
\hline
\end{tabular}

* 50\% z tej powierzchni przeznaczone pod terminal intermodalny

** - docelowa dtugość torów 
Szacowane wielkości przewozów transportem kombinowanym przy założeniu transferu 30\% ladunków z transportu drogowego

Tabela 2

\begin{tabular}{|l|c|c|c|}
\hline & $\mathbf{2 0 1 1}$ & $\begin{array}{c}\mathbf{7 0 \%} \text { prze- } \\
\text { wozów } \\
\text { ladun- } \\
\text { ków>300 } \\
\text { km }\end{array}$ & $\begin{array}{c}\text { 50\% przewo- } \\
\text { zów ladun- } \\
\text { ków>300 km }\end{array}$ \\
\hline $\begin{array}{l}\text { Transport drogowy } \\
\text { [tys. ton] }\end{array}$ & 1596209 & 1117346,3 & 798104,5 \\
\hline $\begin{array}{l}\text { Ilość transferowanego } \\
\text { ladunku (30\%) [tys. } \\
\text { ton] }\end{array}$ & - & 335203,9 & 239431,4 \\
\hline $\begin{array}{l}\text { Ilość transferowanego } \\
\text { ładunku (30\%) [TEU] }\end{array}$ & - & 32863126 & 23473662 \\
\hline $\begin{array}{l}\text { Dodatkowe przeładunki } \\
\text { w przeliczeniu na jeden } \\
\text { terminal } \\
\text { [TEU/terminal] }\end{array}$ & - & 1095437 & 782456 \\
\hline $\begin{array}{l}\text { Transport kolejowy z } \\
\text { uwzględnieniem trans- } \\
\text { feru ładunków [tys. } \\
\text { ton] }\end{array}$ & 248606 & 583810 & 488037 \\
\hline
\end{tabular}

Oszacowane wyżej wielkości są niemożliwe do osiągnięcia przy istniejącej obecnie w kraju infrastrukturze. Średnie możliwości przeładunkowe istniejących terminali lądowych, uwzględniając docelowe parametry terminali, wynoszą zaledwie 71458 TEU rocznie/terminal. Istniejąca infrastruktura jest $\mathrm{w}$ stanie obsłużyć rocznie około 1,5 miliona TEU, a łącznie z terminalami morskimi (przy założeniu, że całość ładunków byłaby transportowana koleją) 3,9 miliona TEU rocznie. Należy przy tym zaznaczyć, że planowany jest rozwój infrastruktury transportu intermodalnego w Polsce. Terminal intermodalny Intermodal Container Yard, który ma powstać z Zajączkowie Tczewskim, zgodnie $\mathrm{z}$ planowanymi parametrami technicznymi ma mieć możliwość przeładunku ponad 1000000 TEU rocznie.

\section{Ocena porównawcza terminali według wybra- nych kryteriów}

W 2011 roku, przy realizacji transportu intermodalnego przez polskich przewoźników kolejowych (którzy obsłużyli około 800 tysięcy jednostek TEU w 2011 roku) wykorzystywano czynnie 26 terminali przeładunkowych [2].

Parametry techniczne funkcjonujących w Polsce terminali są zróżnicowane, podobnie jak ich zasięg i udział $\mathrm{w}$ przewozach intermodalnych. Terminale intermodalne ocenia się najczęściej na podstawie wymogów Umowy AGTC, tj. umowy europejskiej o ważnych międzynarodowych liniach transportu kombinowanego i obiektach towarzyszacych [5].

Poniżej przedstawiono ocenę istniejącej infrastruktury terminali lądowych pod względem ośmiu wybranych kryteriów mających zapewnić sprawne funkcjonowanie i rozwój transportu kombinowanego. Dla wszystkich kryteriów oceny przyjęto punktację w skali od 1 do 5, gdzie 1 było oceną najniższą a 5 oceną najwyższą. W ocenie nie uwzględniono terminali morskich, gdyż terminale te oferują przede wszystkim transport kombinowany drogowo-morski.

Pierwsze trzy kategorie oceny stanowiły podstawowe parametry operacyjne. Pierwszym kryterium pod względem którego zostały porównane obiekty infrastruktury punktowej była liczba torów i ich długość. Według Umowy AGTC pożądana liczba torów wynosi 2, a ich długość to minimum $600 \mathrm{~m}$, docelowo będzie ona zwiększona do $750 \mathrm{~m}$. Rozpatrując sama liczbę torów, to kryterium spełniło 17 terminali z 25 rozpatrywanych, przy czym 2 terminale mają aż 4 tory (terminal w Kutnie i hub w Gądkach). Natomiast 4 terminale nie podają takich informacji, więc nie można było ich porównać. Uwzględniając oba wymogi jednocześnie spełnione są one przez zaledwie 8 terminali (Łódź Olechów, Dąbrowa Górnicza, Pruszków, Gądki, CL Małaszewicze, Kutno, Gliwice, Radomsko). Są one w stanie obsłużyć pełen skład pociąu bez zbędnych operacji rozformowywania.

Drugą kategorię stanowiły możliwości składowania. 6 terminali nie opublikowało takich informacji. Średnie możliwości wynoszą obecnie 1519 TEU, przy uwzględnieniu docelowych parametrów niektórych terminali wartość ta wzrasta do 1664 TEU. Analogicznie łączne możliwości składowe polskich terminali wynoszą $28860 \mathrm{TEU}$, po modernizacji niektórych terminali wielkość składowania wzrośnie o 2750 TEU. Największe możliwości składowe ma terminal Łódź Olechów - 5000 TEU, następnie Kutno - 4000 TEU. Z kolei PCC Intermodal rozbudowuje swoje terminale, tak aby charakteryzowały się lepszymi parametrami. Obecnie terminal w Gliwicach dysponuje placem składowym o pojemności 1650 TEU, docelowo wartość ta ma osiagnać 2900 TEU. Natomiast terminal w Brzegu Dolnym składuje maksymalnie 1000 TEU, jednak docelowo ma osiagnąć wartość rzędu 2500 TEU.

Trzecim porównywanym parametrem były roczne możliwości przeładunkowe. Jak opisano powyżej istniejące $\mathrm{w}$ kraju terminale nie są w stanie obsłużyć wymaganych 30\% ładunków drogowych, które są transportowane na dalekich trasach. Na temat możliwości przeładunkowych informacji udzieliło 19 terminali. Największe możliwości przeładunkowe mają terminal w Kutnie, który ma osiagnąć 200000 TEU rocznie oraz Centrum Logistyczne Malaszewicze 187000 TEU. Na kolejnych miejscach znalazły się Terminal we Wrocławiu z potencjałem 117000 TEU rocznie i Euroterminal Sławków - 105000 TEU. Terminal w Gliwicach, który obecnie obsługuje 50000 TEU, również ma w planach zwiększyć dwukrotnie swoje zdolności przeładunkowe.

Czwartym kryterium wykorzystanym w analizie porównawczej był udział w kolejowych przewozach intermodalnych. Oceny dokonano na podstawie 
danych Urzędu Transportu Kolejowego, który oszacował dla 17-stu terminali strukturę udziałów w rynku przewozów intermodalnych drogowo-kolejowych. Największą wartość osiagnął terminal w Kutnie 8,33\%, dalej CL Małaszewicze - 6,36\%, następnie terminal Cargospedu w Gądkach - 5,55\%, Euroterminal Sławków - 5,06\%. Najmniejszy udział, wynoszący $0,57 \%$ osiagną terminal w Sosnowcu.

Bardzo ważnym aspektem w rozwoju transportu kombinowanego jest lokalizacja na trasie korytarza paneuropejskiego. W tabeli 1 podano informację czy i na trasie którego z korytarzy transportowych znajduje się terminal. Większość terminali w Polsce zlokalizowanych jest na trasie II i III korytarza, jedynie terminal w Mławie, Kątach Wrocławskich, Włocławku i Radomsku mają mniej korzystną lokalizację.

Szóstym parametrem branym pod uwagę $\mathrm{w}$ ocenie była powierzchnia terminala. Wielkości te mieszczą się w przedziale od $6200 \mathrm{~m}^{2}$ w Poznaniu Garbarach do $160000 \mathrm{~m}^{2}$ w Gądkach.

Ostatnie dwie kategorie oceny stanowiły kwestie dojazdu i połączenia $\mathrm{z}$ infrastrukturą liniowa, przy czym siódmą kategorię stanowiła dostępność drogowa terminala z ośrodków gospodarczych, a ósmą łączność z głównymi dalekobieżnymi liniami kolejowymi, a w przypadku przewozów grup wagonów dobre połączenie z szybkimi pociagami towarowymi. Rozpatrywano łatwy i szybki dojazd drogowy oraz połączenie $z$ dalekobieżnymi liniami kolejowymi. W tym celu stworzono graficzny model sieci transportowej z uwzględnieniem dróg krajowych i autostrad oraz ważniejszych linii kolejowych wraz z zaznaczeniem lokalizacji istniejących i planowanych terminali intermodalnych.
Mapa na podstawie której dokonano oceny została przedstawiona na rysunku 1 . Według ostatnich dwóch kategorii najlepsze lokalizacje mają terminale w Łodzi, Gądkach, Gliwicach, Kutnie oraz w Swarzędzu. Szczegółowa punktacja jaką mogły uzyskać terminale w zależności od posiadanych parametrów technicznych wyglądała następująco:

a) Długość torów:

$$
\begin{aligned}
& \mathrm{x}<200 \mathrm{~m} \\
& \mathrm{pkt}) \\
& 200 \mathrm{~m} \leq \mathrm{x}<300 \mathrm{~m} \\
& \text { pkt) } \\
& 300 \mathrm{~m} \leq \mathrm{x}<400 \mathrm{~m} \\
& \text { pkt) } \\
& 400 \mathrm{~m} \leq \mathrm{x}<600 \mathrm{~m} \\
& \text { pkt) } \\
& \mathrm{x} \geq 600 \mathrm{~m} \\
& \text { pkt) }
\end{aligned}
$$

b) Możliwości składowania $\mathrm{x}<600$ TEU

pkt)

$600 \mathrm{TEU} \leq \mathrm{x}<800 \mathrm{TEU}$

pkt)

800 TEU $\leq \mathrm{x}<1000$ TEU

pkt)

1000 TEU $\leq \mathrm{x}<2000 \mathrm{TEU} \quad(4 \mathrm{pkt})$ $x \geq 2000$ TEU pkt)

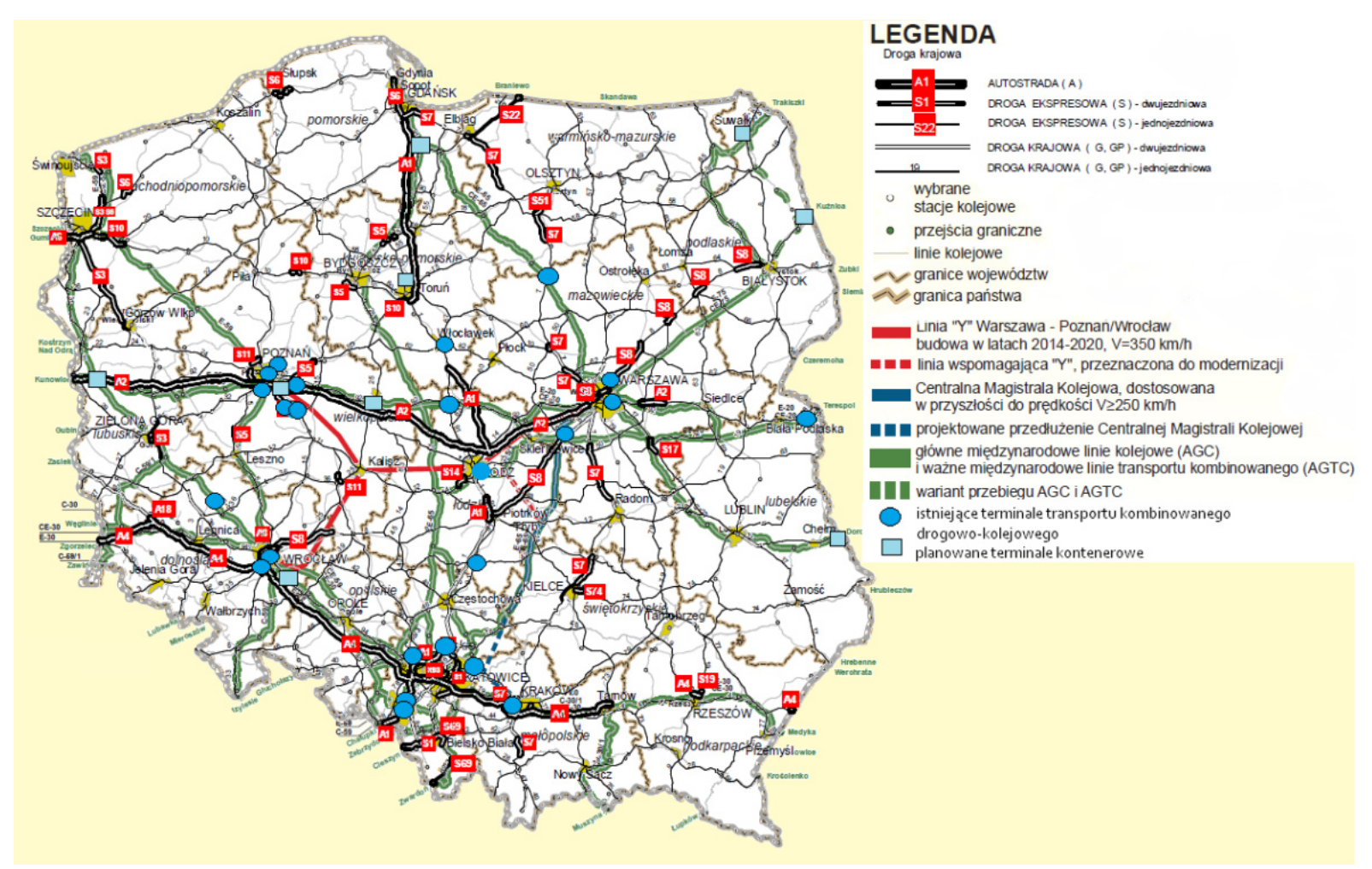

Rys.1. Lokalizacja terminali w stosunku do liniowej infrastruktury drogowej i kolejowej 


\begin{tabular}{|c|c|c|c|c|c|c|c|c|c|}
\hline & 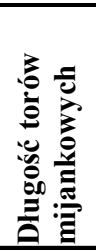 & 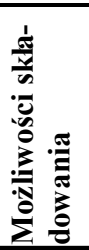 & 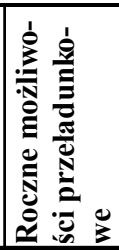 & 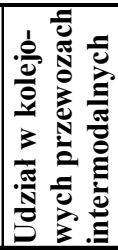 & 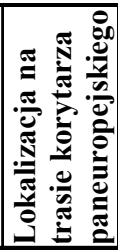 & 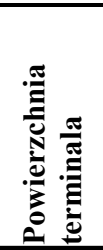 & 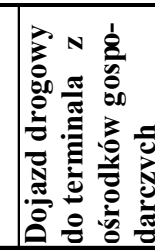 & 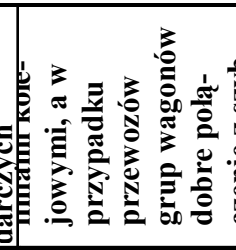 & $\sum_{\infty}^{\mathbb{n}}$ \\
\hline $\begin{array}{l}\text { TK Łódź Olechów } \\
\text { ul. Tomaszowska } 60\end{array}$ & 5 & 5 & 3 & 2 & 5 & 5 & 5 & 5 & 35 \\
\hline $\begin{array}{l}\text { TK Warszawa Towarowa } \\
\text { ul. Ordona 2a }\end{array}$ & 3 & 4 & 2 & b.d. & 5 & 1 & 4 & 5 & 24 \\
\hline $\begin{array}{l}\text { TK Poznań Garbary } \\
\text { ul. Północna } 1\end{array}$ & 1 & 2 & 2 & b.d. & 5 & 1 & 2 & 5 & 18 \\
\hline $\begin{array}{l}\text { TK Sosnowiec Południowy } \\
\text { ul. Kościelna } 60\end{array}$ & 2 & 3 & 2 & 1 & 5 & 1 & 2 & 4 & 20 \\
\hline $\begin{array}{l}\text { TK Kraków Krzesławice } \\
\text { ul. Łowińskiego } 2\end{array}$ & 3 & 2 & 2 & b.d. & 5 & 2 & 3 & 5 & 22 \\
\hline $\begin{array}{l}\text { TK Dąbrowa Górnicza } \\
\text { ul. Koksownicza } 6\end{array}$ & 5 & b.d. & b.d. & b.d. & 5 & 5 & b.d. & b.d. & 15 \\
\hline $\begin{array}{l}\text { TK Pruszków } \\
\text { ul. Przytorowa } 1\end{array}$ & 5 & b.d. & 4 & 4 & 5 & 2 & 1 & 5 & 26 \\
\hline $\begin{array}{l}\text { TK Wrocław } \\
\text { ul. Krakowska } 1\end{array}$ & 2 & b.d. & 5 & 3 & 5 & 3 & 4 & 5 & 27 \\
\hline $\begin{array}{l}\text { TK Gądki } \\
\text { ul. Magazynowa } 8\end{array}$ & 5 & b.d. & 1 & b.d. & 5 & 5 & 5 & 5 & 26 \\
\hline $\begin{array}{l}\text { TK Mława } \\
\text { ul. Dworcowa } 9\end{array}$ & 3 & 3 & 3 & 2 & 1 & 2 & b.d. & b.d. & 14 \\
\hline $\begin{array}{l}\text { TK Kobylnica } \\
\text { ul. Dworcowa } 3 \\
\end{array}$ & 3 & 1 & 1 & 2 & 5 & 1 & 4 & 3 & 20 \\
\hline $\begin{array}{l}\text { TK Gądki } \\
\text { ul. Dworcowa } 32\end{array}$ & 3 & 4 & b.d. & 5 & 5 & 1 & 5 & 5 & 28 \\
\hline $\begin{array}{l}\text { TK Warszawa } \\
\text { ul. Marywilska } 39\end{array}$ & 3 & 4 & 4 & 4 & 5 & 2 & 4 & 4 & 30 \\
\hline $\begin{array}{l}\text { TK Gliwice } \\
\text { ul. Reymonta } 32\end{array}$ & 4 & 4 & 4 & 3 & 5 & 4 & 5 & 5 & 34 \\
\hline $\begin{array}{l}\text { TK CL Małaszewicze } \\
\text { ul. Kolejarzy } 22 \mathrm{~b}\end{array}$ & b.d. & 4 & 5 & 5 & 5 & 1 & 4 & 5 & 29 \\
\hline $\begin{array}{l}\text { TK Sławków LHS } \\
\text { ul. Dębowa Góra }\end{array}$ & b.d. & b.d. & 1 & 3 & 5 & b.d. & 4 & 4 & 17 \\
\hline $\begin{array}{l}\text { TK Kutno Krzewie } \\
\text { ul. Intermodalna } 5 \\
\end{array}$ & 5 & 5 & 5 & 5 & 5 & 5 & 5 & 5 & 40 \\
\hline $\begin{array}{l}\text { TK Gliwice } \\
\text { ul. Portowa } 28\end{array}$ & 5 & 4 & 3 & 5 & 5 & 2 & 4 & 5 & 33 \\
\hline $\begin{array}{l}\text { TK Brzeg Dolny } \\
\text { ul. Sienkiewicza } 4\end{array}$ & 3 & 3 & 1 & 4 & 5 & 1 & 3 & 5 & 25 \\
\hline $\begin{array}{l}\text { TK Kąty Wrocławskie } \\
\text { ul. Fabryczna } 1\end{array}$ & 5 & 3 & b.d. & 2 & 1 & b.d. & 3 & 2 & 16 \\
\hline TK Włocławek Brzezie & b.d. & b.d. & b.d. & 2 & 1 & b.d. & 5 & 3 & 11 \\
\hline $\begin{array}{l}\text { Euroterminal Sławków } \\
\text { ul. Groniec } 1\end{array}$ & b.d. & 5 & 5 & 5 & 5 & b.d. & 3 & 5 & 28 \\
\hline $\begin{array}{l}\text { TK Poznań } \\
\text { ul. Nowosolska } 40\end{array}$ & 3 & 4 & b.d. & b.d. & 5 & b.d. & 3 & 5 & 20 \\
\hline $\begin{array}{l}\text { TK Radomsko } \\
\text { ul. Kraszewskiego } 36\end{array}$ & 5 & 5 & b.d. & b.d. & 1 & b.d. & 4 & 5 & 20 \\
\hline $\begin{array}{l}\text { CLIP Logistics Swarzędz } \\
\text { ul. Rabowicka } 6\end{array}$ & b.d. & 3 & b.d. & b.d. & 5 & 1 & 5 & 5 & 18 \\
\hline
\end{tabular}


c) Roczna zdolność przeładunkowa $\mathrm{x}<30000 \mathrm{TEU}$

pkt)

$30000 \mathrm{TEU} \leq \mathrm{x}<50000 \mathrm{TEU}$

pkt)

$50000 \mathrm{TEU} \leq \mathrm{x}<80000 \mathrm{TEU}$

pkt)

80000 TEU $\leq \mathrm{x}<100000$ TEU

pkt)

$\mathrm{x} \geq 100000$ TEU

pkt)

d) Udział w kolejowych przewozach

intermodalnych

$\mathrm{x}<1 \%$

pkt)

$1 \% \leq \mathrm{x}<2 \% \quad$ (2 pkt)

$2 \% \leq \mathrm{x}<3 \% \quad$ (3 pkt)

$3 \% \leq \mathrm{x}<4 \% \quad$ (4 pkt)

$x \geq 4 \%$

pkt)

e) Lokalizacja na trasie TEN-T

TAK

pkt)

NIE

pkt)

f) Powierzchnia terminala

$\mathrm{x}<20000 \mathrm{~m} 2$

pkt)

$20000 \mathrm{~m} 2 \leq \mathrm{x}<40000 \mathrm{~m} 2$

$40000 \mathrm{~m} 2 \leq \mathrm{x}<60000 \mathrm{~m} 2$

pkt)

$60000 \mathrm{~m} 2 \leq \mathrm{x}<80000 \mathrm{~m} 2$

pkt)

$\mathrm{x} \geq 80000 \mathrm{~m} 2$

pkt) temowie AGTC, co staje sie bariera rozwoju tanch umowie AGTC, co staje się barierą rozwoju transportu intermodalnego. Przede wszystkim brakuje torów wyładunkowych o odpowiedniej długości (minimum 600 metrów), stan nawierzchni płyty terminali oceniany jest jako zły, większość terminali ma niewłaściwy profil powierzchni placów składowych, a także sama ich powierzchnia jest mała, brakuje nowoczesnego sprzętu oraz niewystarczająco rozwinięta jest infrastruktura około terminalowa. Przykładem terminalu intermodalnego, który nie jest przystosowany do efektywnej realizacji przeładunków jest terminal Poznań Garbary, należący do operatora Spedcont. Największą barierą $\mathrm{w}$ rozwoju tego terminala jest jego usytuowanie $\mathrm{w}$ centrum miasta. Jego lokalizacja sprawia, że brakuje dojazdu droga o wymaganych parametrach technicznych. Przy założeniu zwiększenia przeładunków w polskich terminalach ten nie będzie w stanie realizować obsługi odpowiedniej liczby jednostek ladunkowych.

Obecnie coraz powszechniejsze staje się inwestowanie w rozwój centrów logistycznych, które oferują nie tylko przeładunek, składowanie kontenerów, ale również szereg innych usług. Także nowo powstające terminale intermodalne są już budowane $\mathrm{z}$ myślą o zapewnieniu jak najlepszej obsługi, a także o wywiązaniu się z podstawowych wymagań stawianych tego typu inwestycjom.

Aktualny stan infrastruktury nie pozwala na przejęcie $30 \%$ ładunków z transportu drogowego przez transport kolejowy. Żeby tak się stało należy przeprowadzić zakrojone na szeroką skalę inwestycje związane $\mathrm{z}$ budową nowych terminali oraz modernizacja tych istniejących przy czym tylko tych, które oferują perspektywy rozwoju transportu kombinowanego i maja odpowiedni potencjał. Obecne możliwości przeładunkowe terminali są niewystarczające lub też nie w pełni wykorzystywane. Polska dysponuje na chwilę obecna 9-cioma terminalami i centrami logistycznymi, które są w stanie przejąć duże ilości ładunków. Wśród nich znajdują się terminale w Łodzi, Gądkach, Warszawie Kutnie, Sławkowie, Małaszewiczach, Swarzędzu oraz dwa w Gliwicach. Sa to najlepiej oceniane terminale ze względu na kryteria użyteczności. Nowe inwestycje 
jakie są w planach mają charakteryzować się coraz lepszymi parametrami operacyjnymi, a zatem mogą $\mathrm{w}$ dużej mierze przyczynić się do rozwoju transportu kombinowanego.

\section{Literatura:}

[1] Kisperska-Moroń D., Krzyżaniak S., Logistyka, Wyd. ILiM, Poznań 2009.

[2] Analiza rynku kolejowych przewozów intermodalnych, Urzad Transportu Kolejowego, Warszawa 2012.

[3] Biała Księga pt. Plan utworzenia jednolitego europejskiego obszaru transportu - dażenie do osiagnięcia konkurencyjnego $i$ zasobooszczędnego systemu transportu, Komisja Wspólnot Europejskich, COM (2011) 144, Bruksela 2011.
[4] Rocznik statystyczny Transport. Wyniki działalności w 2011 roku, Główny Urząd Statystyczny, Warszawa 2012.

[5] Umowa europejska o ważnych międzynarodowych liniach transportu kombinowanego $i$ obiektach towarzyszacych (AGTC), M.P. nr 3 poz. 50, 2004.

[6] Zielaskiewicz H., Terminale przeładunkowe w Polsce. Problemy techniczne $i$ projektowe - cz. 1, Infrastruktura Transportu 4/2012, s. 50-54. 